Semmelweis Orvostudományi Egyetem

Honvéd-Katasztrófa-Rendvédelem-Orvostani Tanszékcsoport

\title{
A Magyar Néphadsereg Egészségügyi Szolgálatának története 1980-1989 (III. rész)
}

\section{Prof. Dr. Svéd László ny. orvos altábornagy, PhD}

Kulcsszavak: Egészségügyi Szolgálat, harmadik világ és a fejlődö országok, Varsói Szerződés, „Jemeni Magyar Barátság” kórház, segélyezés, humanitárius segély, útijelentés, Országgyülés Honvédelmi Bizottsága (HB)

\begin{abstract}
A Hadtörténeti Intézet felkérése alapján 2016 őszétől 2017 végéig végeztem kutatásokat az Intézet Levéltárában a Magyar Néphadsereg Egészségügyi Szolgálatának 1980-1989 évek közötti történelmének objektív tényeken alapuló leírására. Az előző két részben az alaprendeltetésről, illetve a mindennapok egészségügyi biztosítási, ellátási feladatairól, azok eredményeiről, nehézségeiröl és emlékeiről olvashattunk. Most az abban az időben is bizalmasan kezelt nemzetközi kapcsolatok helyszíneivel, feladataival és egészségügyi specialitásaival ismerkedhetünk meg. Végezetül egy külön fejezetrész foglalkozik az akkori tárcavezetés egészségügyi szolgálatra vonatkozó megítélésével.
\end{abstract}

Nemzetközi kapcsolatok, együttmüködési feladatok

Az MN egészségügyi szolgálata külföldi kapcsolatai és az együttműködési feladatok két irányban valósultak meg.

Az egyik a Varsói Szerződés tagállamaival (VSZ) való kapcsolattartás, amely az egészségügyi szolgálatfönök és a föszakorvosok koordinációs értekezleteiből, konferenciából állt. A másik fő irányt az ún. harmadik világ és a fejlödő - elsősorban afrikai és közel-keleti országok különbözö nagyságú és arányú „segélyezési” feladatai képezték. Ezen kívül néhány kiemelkedő tudású orvosnak engedélyezték az adott szakterület világvagy európai kongresszusán való részvételt.

Az MN egészségügyi szolgálata tagja volt a Nemzetközi Katonaorvosi Társaságnak [International Committee of Military Medicine (ICMM)] is. A társaság éves kongresszusain a szolgálat szinte minden alkalommal képviseltette magát.

A VSZ tagállamai katona-egészségügyi szolgálata vezetői állománya részére Magyarország rendezte $a X V$. Koordinációs értekezletet 1985. október 09-18. között [42].

Az ún. „fejlődő” országokkal való együttmüködésben - melynek koordi- 
nációja és szervezése HM szinten valósult meg - az egészségügy szinte minden területen és érintett országban példásan teljesítve vett részt.

A legszélesebb és a legtöbb problémát okozó együttmüködés a Jemeni Népi Demokratikus Köztársasággal (JNDK) volt. Ebből az országból az MN Központi Katonai Kórház (KKK) az 1977. áprilisa óta - az érvényben lévő egészségügyi megállapodás alapján - rendszeresen fogadott betegeket gyógykezelésre. Az elvégzett feladatokról és az újabb kérésekről szinte évente tartottak egyeztetéseket. Így történt ez All Anter által vezetett katonai küldöttség 1980. június 23-25. közötti magyarországi látogatása során is. A látogatásra való felkészülés, illetve a tárgyalási dokumentumok hüen tükrözik mindazokat a nehézségeket, és feladatokat, amelyekkel a HM vezetése a nemzetközi kapcsolatok terén és az egészségügy a 80 -as évek során szinte folyamatosan szembesült.

A különböző szintü látogatások célja szinte mindig a két ország honvédelmi minisztere által 1979. februárjában Ádenben aláírt együttműködési „Megállapodás" áttekintése volt, melynek során kiemelten foglalkoztak a katona-egészségügyi megállapodás végrehajtásának helyzetével. Az 1980-as találkozó nyitótárgyalásán a magyar delegációt vezető honvédelmi miniszter az alábbiak szerint értékelte az előző évet és tekintett elöre a következőre. „Folytattuk a jemeni betegek magyarországi gyógykezelését (1979-ben 33 fö). A közelmúltban adtuk meg újabb 10 beteg és 5 kísérő fogadására vonatkozó készségünket. A „Jemeni Magyar Barátság Kórházhoz" 5 orvost és 3 fö asszisztenst vezényeltünk. A jelenlegi csoport év végéig fog Önöknél tartózkodni, a változásokhoz a szükséges elökészületeket már megtettük.
Egészségügyi technikusunk a múlt év novemberében kiutazott és elvégezte az egészségügyi eszközök karbantartási és javítási munkáit. A kórház működtetéséhez szükséges egészségügyi anyagokat a segélyszállítmánnyal együtt múlt év júliusában szállítottuk ki.

Egészségügyi szakembereink Ádenben egyeztették Önöknél az 1980-ban átadásra kerülő egészségügyi anyagokat, a szállítmány előkészítése folyamatban van, várhatóan augusztus hónapban indítjuk útba Ádenbe.

A múlt év szeptemberében 5 jelöltet fogadtunk egészségügyi asszisztens képzésre. Az idén beiskolázásra kerülő újabb 5 före fogadási készségünket megadtuk. Várjuk, hogy a hallgatók augusztusban megérkezzenek.

Ugyancsak megadtuk fogadó készségünket 1 fó katonaorvos 6 hónapos szakmai továbbképzésére vonatkozóan.

A múlt év augusztusában egészségügyi szolgálatuk vezetője 3 munkatársa kíséretében Magyarországra látogatott. Részükre a béke és háborús egészségügyi ellátás kérdésében az igényelt konzultációt biztosítottuk.

$\mathrm{Az}$ évente átadásra kerülő 20000 adag kombinált oltóanyagot a januárban kiutazott orvoscsoport magával vitte és átadta az Önök részére.

Egészségügyi szakembereink novemberben az Önök egészségügyi szolgálatának vezetőjével közösen a helyszínen megvizsgálták fertőző osztály felállításának lehetőségét a „Jemeni Magyar Barátság Kórházban". A mi szakembereink véleménye szerint a fertőző osztály a kórház bővítése nélkül az épületrész lezárásával kialakítható, működtetése a jelenlegi létszámmal, illetve az évente kiszállítandó egészségügyi anyagokkal biztosítható. A jemeni fél ezt a megállapítást nem tette magáévá és közölte, hogy a kórház bö- 
vítését célzó javaslatot fog előterjeszteni a jemeni honvédelmi minisztérium vezetése részére. Ismételten megerősítette a miniszter, hogy építési munkák végzésére nem tudunk vállalkozni. Elmondta továbbá, hogy a kórház kapacitása jelenleg nincs teljes mértékben kihasználva. Szakembereink üresen álló kórtermeket találtak. Érthetetlen, hogy ez a helyzet mind a mai napig fennáll. A jelenlegi 40-45\%-os kihasználtság azt követeli, hogy a fertőző osztályt belső átszervezéssel alakítsák ki és engedélyezzék a hozzátartozók gyógykezelését is. A felsorolások végén a miniszter nyomatékosan kérte, hogy a szükséges és ésszerü intézkedéseket haladéktalanul tegyék meg (0183/49/1980. HM titkárság) [60]”.

Újabb fejezetet, illetve a továbbiak folytatását jelentette az 1983. március 30-tól április 03-ig itt tartózkodó JNDK katonai küldöttségének látogatása. Ennek az évnek a végén ugyanis a katona-egészségügyi és az ádeni központi harcálláspont üzemeltetésére vonatkozó 1979-ben és 1980-ban, majd 1981-ben az MN VKF által aláírt „Megállapodások" érvényessége lejárt. Az 1983 tavaszán történő látogatásra a HM titkárság egy összegző anyagot állított össze az addig történtekről. Ez alapján 1979 óta 80 beteget fogadtunk, orvosokat és asszisztenseket vezényeltünk a „Jemeni Magyar Barátság Kórház"-ba. A váltások mindig rendben megtörténtek. Évente elvégeztük a kórház berendezéseinek ellenőrzését, karbantartását, javítását. Évi 2,5 mFt értékben térítésmentesen kiszállítottuk a kórház müködéséhez szükséges szakanyagokat. Évente 20000 adag oltóanyagot szállítottunk ki térítésmentesen. 1979 óta évente 5 föt fogadtunk egészségügyi középkáder képzésre. A hallgatók első csoportja 1982-ben fejezete be tanulmányait. Jelenleg 15 fő részére fo- lyik képzés. Kérésük alapján szakorvosi vizsga letételére fogadtuk két orvosukat. Többszöri szorgalmazásunk ellenére nem alakítottak ki állandó orvos, ápolói és asszisztensi gárdát a kórházban. Ez nagymértékben hátráltatta és hátráltatni is fogja a kórház gyógyító tevékenységét. Az ágykihasználtság terén az utóbbi 1-1,5 évben tapasztalható észrevehetö javulás (jelenleg 80\%-os az ágykihasználtság). Elvárjuk, hogy a nálunk végzett egészségügyi szakemberek orvosainkkal együtt dolgozzanak a "Jemeni Magyar Barátság Kórháznál." (8/00629. HM titkárság 35. old.) [61].

Új vállalásként 1983. év végéig az MN az alábbi vállalásokat ajánlotta fel, illetve ígérte meg:

„Évi 10 fő katonabeteg gyógykezelése térítésmentesen, ami eddig nem volt meghatározva. A szakállomány vezénylésével felmerülő költségek jemeni fél által történő térítése mellett továbbra is biztosítjuk 4 orvos és 4 asszisztens vezénylését a kórházhoz. Hasonló feltételekkel biztosítjuk évenként egy alkalommal a szaktechnikust (eddig mi fizettük). Évenként 5 fö jemeni egészségügyi középkáder és 1 fö szaktechnikus 6 hónapos térítésmentes képzését vállaljuk. Évente térítésmentesen 20000 adag kombinált oltóanyagot és $2,5 \mathrm{mFt}$ értékben magyar gyártmányú gyógyszereket, egészségügyi textíliákat és műszerek átadását, szállítását biztosítjuk." (8/00629. HM titkárság 38, 41. o.) [61].

„Javasolják, hogy a magyarországi illetmény mellé a jemeni fél 10 dollár kiegészítést adjon." (8/00629. HM titkárság 42. old.) [61].

A tárgyalás végén egy pontosított „Megállapodás” került aláírásra. Ennek megfelelően az egyes személyek kiküldetésének időtartama egy év, de a felek megállapodhatnak rövidebb vagy hosz- 
szabb időtartamban is. A Magyar Népköztársaság az alábbi US dollár illetményt folyósítja:

Egy éven belül:

- orvos 450-600 US dollár

- asszisztens 400-500 US dollár

Egy éven túl:

- orvos 550-800 US dollár

- asszisztens 550-650 US dollár.

Aki egy éven túl vállalt szolgálatot, az jogosult volt családtagját is magával vinni. A feleségnek az illetmény $20 \%$-át, a 12 éven felüli gyerek után 15\%-át, a 12 éven aluli gyerek után 10\%-át fizették. A jemeni fél teljes ellátást, fürdőszobás, légkondicionált, bútorozott, fözési lehetőségekkel rendelkező lakást (lakásokat) volt köteles biztosítani. Az „együttmüködési irányelveket" 1985 . december 31ig érvényben lévőként írták alá a tárgyalások végén 1983. áprilisában.

Az irányelvek külön jegyzéken tartalmazták az $\mathrm{MN}$ gyógyintézeteiben magasan kvalifikált szinten ellátható sérülési típusokat, és megbetegedési korformákat. Végül az irányelv évi 10 beteg ellátásról szólt úgy, hogy egy időben 5 fö tartózkodhatott itt. A sebészeti beavatkozások mindegyike rekonstrukciós mütétekre vonatkoztak. (8/00629 HM titkárság, 52, 56-58. old.) [61].

Rácz Sándor altábornagy 1983. októberi, illetve Pacsek József altábornagy 1985-ös - a delegáció tagja volt Dr. Hideg János orvos vezérörnagy, MN. Eü. Sz.F. is - jemeni látogatását 1987. október 10-15. között viszonozta Saleh Obesd Ahmed ezredes a JNDK honvédelmi minisztere. Ez alkalommal is áttekintették az együttmüködési megállapodást és körvonalazták a kórház müködésének végét, illetve az új feltételeket. Az 1985-ben aláírt „Megállapodás" óta eltelt időszak feladatait összegezve a felek által teljesítetteket áttekintve megállapították, hogy a „Jemeni Magyar Barátság Kórházban” 1987. március 31-ig teljesítettek szolgálatot orvosaink. Ez az időtartam közel egy évvel hosszabb volt, mint amit az aláírt dokumentum meghatározott és amelynek oka az 1986-os jemeni események voltak. 279 beteg kapott Magyarországon gyógykezelést. A tárgyalás időszakában 11 fö beteg tartózkodott az MN gyógyintézeteiben. 1986. január 01-től 10 fő egészségügyi középkáder képzésére, 25 főt pedig gyógykezelésre fogadtunk Magyarországon. 1986ban $2 \mathrm{mFt}$ értékben gyógyszer, kötszer és élelmiszer, valamint 20000 adag oltóanyag térítésmentes átadásával segítettük a kórház üzemelését.

A tárgyalások során tájékoztatták a JNDK honvédelmi miniszterét, hogy amennyiben kéri orvosaink vezénylésének felújítását - tekintettel gazdasági nehézségeinkre -, erre csak a jemeni fél teljes költségtérítésével, külkereskedelmi szerződés keretében látnak lehetőséget. Ebben az esetben 4 fó orvos vezénylésére van lehetőség. A magyar fél továbbra is fogad évente 15 fö beteget, és megteremtik a lehetőségét annak, hogy sürgős esetben e létszámon felül is fogadjunk néhány beteget. Változatlanul térítésmentesen biztosítottuk 20000 kombinált oltóanyag - és a kórház munkájához kisebb mennyiségű gyógyszerek átadását. Ennek végrehajtását ekkor már jelentősen segítette az épp ekkor a jemeni légitársaság által beindított közvetlen budapesti repülöjárat (14/00452 HM titkárság, 5, 9, 91, 93, 96-97. old.) [61].

A líbiai fegyveres erök föparancsnokának 1980. május 31. és június 03. közötti látogatására jelentős egészségügyi együttmüködés lehetősége került felajánlásra. A magyar fél ezzel összefüggésben lehetőséget látott arra, „hogy a líbiai fél korábban bejelentett igénye 
alapján katonai szakorvosokat és egészségügyi középkádereket vezényeljen a líbiai fegyveres erők kórházaiba. A líbiai fél erre vonatkozó konkrét igényét július végéig tervezte közölni a magyar féllel. A magyar fél biztosítani tudja továbbá tapasztalatok átadását, illetve konzultációk megtartását a katona-egészségügy béke és háborús irányok közötti tevékenységgel összefüggésben." (8/00502/1982. HM titkárság, 38, 430. old.) [60].

A honvédelmi miniszter a líbiai föparancsnoknak elmondott tájékoztatójában egyéb lehetőségeket is felajánlott. „Másik ilyen terület a katonai egészségügy és a gyógyítás mobillá tétele. Arra törekszünk - és itt nagyon jó bázisunk a világhírü Medicor Művek -, hogy a tábori sebészettől a röntgenig minden vizsgálatot mozgó berendezésekkel lehessen végezni... Ezeket a berendezéseket széles körben alkalmazzák a hadseregben... Ugyancsak ilyen berendezés a tü nélküli oltópisztoly... Ezt a berendezést egyébként a VSZ hadseregeinél is rendszeresítették." A látogatás során a felajánlott műszereket és eszközöket (tábori műtőkonténer, tábori röntgen, közúti autóbusz sebesültszállító készlettel, KTD-1, KTD-2, KTA-4 komplex diagnosztikai táskák, automatikus repülőgépvezető ellenőrző orvosi műszer, KOBRA-1 tünélküli oltópisztoly) technikai bemutató keretében a föparancsnoknak be is mutatták (0196/41/1980. HM tájékoztatója a föparancsnoknak, 50, 54, 57. old. [60]).

A nigériai légi marsall által 1982-ben vezetett delegációnak az MN ROVKI (Kecskemét) részéről megajánlották nigériai repülőorvosok képzését. A hajózó állomány pszichológiai vizsgálatára kifejlesztett, „Balaton” típusú műszert is bemutatták, amely a komplex pszichés teljesítmény mérésére szolgált. Ez az eszköz az első magyar ürrepülésen is jelen- tős szerepet kapott. Megismertették a delegációt a KTD-8 komplex diagnosztikai táska képességeivel, amely a pilóták legfontosabb élettani funkcióinak ellenőrzését tette lehetôvé a felszállás elött [62].

$A z$ Etiópiával felvállalt együttmüködés keretében 1980-ra nyúlott át az egészségügyi káderek magyarországi képzése, melyen 43 fő nyelvi előkésztő után 10 hónapos tanfolyamon vett részt az MN egészségügy bázisain [63].

Bissau-Guineai honvédelmi miniszter 1981. július 11-16. között látogatott hazánkba. 1980-ban sikeresen - a HM vendégeként - gyógykezeltek az $\mathrm{MN}$ KKK-ban „maláriás” megbetegedéssel 1 fö tisztet. A miniszter kérte, hogy a magyar fél 1981 és 1985 közötti időszakban további gyógykezelések végrehajtását biztosítsa [60].

Az angolai katonai küldöttség 1983. április 25-30. közötti itt tartózkodása során pontosították az eddig vállaltakat, illetve további segélyek átadásáról, kiszállításáról egyeztettek. Ennek alapján 1983-84 évi időszakban 20 fó angolai katonabeteg gyógykezelését vállaltuk. A betegek első csoportja (10 fö) 1983 márciusában meg is érkezett. Megállapodtak, hogy a katonabetegek 10 fös csoportokban érkeznek fél évenként, miután az előző 10 fő kezelése befejeződött. Vállaltuk, hogy 1983-ban és 84-ben, évente 25000 adag kombinált oltóanyagot adunk át térítésmentesen. Az 1983ban esedékes mennyiséget szeptember végéig juttatták ki Luandába. (8/00630. HM titkárság, 50. old.) [60].

További segélynyújtásként $6 \mathrm{db}$ kötözőasztalt, $12 \mathrm{db}$ müszerkészletet a kötözőasztalhoz, 150 hőpalackot, $100 \mathrm{db}$ jégpalackot, 200-200 ampulla vércsoport meghatározó reagenst, $50-50000 \mathrm{db}$ fenil, klion, pipolphen, tavegil, videx tablettát, 100 ampulla gentamicint és 2000 
liter 5\%-os szőlőcukor 1000 ml-es infúziós oldatot adtunk át (8/00630. HM titkárság, 145. old.) [60].

$\mathrm{Az}$ afganisztáni háborús sérültek ellátásából sem maradtunk ki. $\boldsymbol{A z} \boldsymbol{A} \boldsymbol{f g a}$ nisztáni Demokratikus Köztársaság további sebesülteket küldött. 1986-ban 5 fő gyógykezelését vállaltuk [43].

Végezetül és nem utolsó sorban fontos momentumként említem, hogy az MN KKK rekonstrukciója és annak megtervezése során meghatározó volt az MN HF 1984-es májusi látogatása a Jugoszláv Néphadsereg hadtáp szolgálatánál.

$\mathrm{Az}$ 1985. februári HM KT elé terjesztett anyagra Oláh István vezérezredes kritikai megjegyzést tett, illetve megkérdezte: „Hol, mikor, kik terveznek más szocialista országban tapasztalatot szerezni? (Prága, Belgrád, pl.) Kikkel (szakemberek) lett ez lekonzultálva??" [39]. Az útijelentés erre csattanós választ adott. „Ezen akadémia (Belgrád, Jugoszlávia Katonai Orvosi Akadémiája, sic.a szerző) a közelmúltban készült 14 emeletes, korszerü, komputerizált gyógyászati-technikai eszközökkel felszerelt objektum, amely egyesíti magában az egészségügyi szolgálat tudományos-kutató, katona-egészségügyi kiképző, továbbképző központját, valamint 1250 ággyal rendelkező kórházat (benne a legfelsőbb párt és állami vezetést kiszolgáló részleget). A katonai egészségügyi kárderek szakmai fejlődésének érdekében engedélyezték azt, hogy a körzeti katonai kórházakban 30, a katonai egészségügyi akadémián pedig $50 \%$-os arányban nem honvédségi dolgozók gyógyításával is foglalkozhatnak."

„Mivel a központi kórház rekonstrukciója előtt állunk, ezért hasznosnak tartanánk, ha néhány szakemberünk a jelentett egészségügyi akadémiát tanulmányozná. A jogszláv fél kérésünknek megfelelö idő- pontban kész a fogadásra." [8/00868. HM titkárság, 19, 21, 22. old. [64].

A látogatásra Dr. Vittek László o. ezredes vezetésével sor is került, és a tapasztalatok teljes mértékben beemelésre kerültek a rekonstrukciós elképzelésekbe.

\section{A Magyar Néphadsereg egészségügyi szolgálatának HM tárca szintü megítélése 1980-1989 között}

Ezt a fejezetet egy nagy összegzésnek tekinthetjük, ami a végszót is jelenti az igencsak sok eseményben és feladatokban gazdag 80-as évek Magyar Néphadseregéről.

Az előző fejezetekben megírt objektív tények és a valóságban bizonyos szinteken megélt történelem az Országgyülés Honvédelmi Bizottságának megtett jelentéseiben köszönnek vissza, rendkívüli tömörséggel megfogalmazva [63]. Tanulságos a társadalmi-gazdasági-politikai változások erősödő hatásának tükröződése, látható és érzékelhető a jelentésekben a szakmaiságtól a gazdaságossági racionalizálásig való eljutás. Az utolsó évek jelentéseiben tükröződik a társadalmi változások iránti igény. Ezek után idézzük fel, mindenféle kommentár nélkül - esetenként azért bizonyos megjegyzéseket megengedve - a száraz, de nagyon körültekintően megfogalmazott, csak és kizárólagosan az egészségügyi szolgálatot érintő szövegrészeket, megítéléseket.

\section{0. évi beszámoló az Országgyülés Honvédelmi Bizottságának}

Erről az évről két forrás is rendelkezésre áll. Az első feltehetően a jelentés egy változatban - tervezetként - a vezetésnek való bemutatásra készült, amelyet a Ve- 
zérkari főnök nagyon „levegösnek”, tényszerütlennek és a felhozott példákat nem odavalónak ítélt meg. A tervezet az akkor még csak „elgondolt” hatodik ötéves tervre (1981-85) is elöremutatott. Erről a következőket írja: „A hatodik ötéves tervidőszak jelentős egészségügyi, szociális és kommunális célkitüzései keretében legjelentősebb a 300 ágyas győri kórház építésének befejezése, a pécsi kórház bővítése, a kecskeméti és nagykanizsai rendelő építése" (15. old.).

„A csapatorvosi helyek feltöltési arányszámának növelése, a csapatgyengélkedők felszereltségének folyamatos javitása eredményeként az egészségügyi alapellátás színvonala megfelel a követelményeknek."

„Az intézeti ellátásban tervezett és megvalósult fejlesztések, beruházások javították a hatékonyabb gyógyító munka minőségi feltételeit. A tervidőszak beruházásai - a hévízi szanatórium 150 ágyas bővítése, a balatonfüredi szívszanatórium - növelték és bővítették az egyes megbetegedések gyógykezelési és rehabilitációs lehetőségeit.(MN VK AGTCSF 0085/156/1976. 22-23. old.) [63].

Ezzel szemben az 1980-as évről elhangzott, és leírt HB beszámoló - amelyet december 9-én tartottak meg - már nem erről szól, hanem arról, hogy „az egészségügyi ellátásban az elmúlt tervidőszakban nem sokat fejlődtünk, helyenként a polgári ellátás színvonalát sem érjük el" [MN VK AGTCSF 0085/58/1976. 15. old.) [63].

\section{1. évi beszámoló az Országgyülés Honvédelmi Bizottságának}

„....az egészségügyi ellátás színvonalának fejlesztése, korszerüsítése terén tovább javította a gyógyító-megelőző munka személyi és tárgyi feltételeit, folytattuk a csapatrendelők felújítását, új, korszerűbb eszközökkel történő ellátását. Megkezdtük a kecskeméti katonai kórház bővítését. Tervszerüen halad a győri katonai kórház építése (9. old.)".

„Az év során változatlanul magas számban váltak ki a hivatásos állományból a felső korhatár elérése előtt, ezek 80\%-a egészségügyi okok miatt"[MN VK AGTCSF 0085/62/1976. (11. old.) [63]].

\section{2. évi beszámoló az Országgyülés Honvédelmi Bizottságának}

„A személyi állomány életkörülményeit jelentősen befolyásoló egészségügyi ellátásról elmondhatom, hogy az ellátandók számának növekedése ellenére - erőfeszítéseink eredményeként - szerény mértékben tovább javult. Ez évtől müködik Nagykanizsa helyőrségi csapatrendelö, amely első kísérleti tagja a jövőben kiterjesztésre tervezett helyőrségi szintü ellátási rendszernek. Ugyanakkor súlyos gondot jelent számunkra, hogy a visszafogott keretlehetőségek miatt a két elavult fóvárosi kórházunk rekonstrukcióját nem tudjuk tervezett elgondolásaink szerint megkezdeni. Kórházaink ágykihasználtsága közel 80\%, a szanatóriumok $90 \%$ körüli. Kórházainkban az egy betegre jutó ápolási idő az országos átlaghoz hasonló, 14,2 nap.

$\mathrm{Az}$ egészségügyi ellátásban előttünk álló feladat: a győri katonai kórház munkájának beindítása; csapatrendelőink és kórházaink folyamatos fejlesztése, müszerezettségük emelése; egy betegotthon létrehozása Veröcemaroson, valamint a csapatorvosok utánpótlási és egyéb problémáinak mielőbbi rendezése." (MN VK AGTCSF 0085/71/1976. 15. old.) [63]. 


\section{3. évi beszámoló az Országgyülés Honvédelmi Bizottságának}

„A személyi állomány egészségügyi ellátása és egészségügyi állapota, ha szerény mértékben is, de tovább javult. A szürövizsgálatok szerint a sorállománynál a gyakorlatilag egészségesek aránya 96,5\%, a hivatásos állománynál közel $80 \%$.

Kórházaink ágykihasználtsága 80\%os, az egy betegre jutó 14 napos ápolási idő összességében kedvezőnek ítélhető, megegyezik az országos átlaggal.

$\mathrm{Az}$ egészségügy vonalán elsősorban a csapatorvosi ellátottság terén vannak problémáink. A csapatorvosi feltöltöttség az 1979. évi 83\%-ról jelenleg 61\%-ra csökkent. Pótlásuk sororvosokkal történik, de ez hosszú távon nem jelenthet megoldást." (MN VK AGTCSF 0085/73/1976. 11. old) [63].

\section{4. évi beszámoló az Országgyülés Honvédelmi Bizottságának}

„Ebben az évben befejeződött a pécsi kórház bővítése, a kecskeméti rendelőintézet és gyógyszertár, az új 300 ágyas győri kórház építése, az MN Központi Katonai Kórházban az égési osztály és a művese állomás kialakítása. Kiemelt feladatként megkezdtük az MN 1. sz. Katonai Kórház átfogó felújítását, a Verőcemarosi Betegotthon kialakítását, valamint az MN Központi Katonai Kórház rekonstrukciója előfeltételeként egy kiváltó körlet építését." (6. old.).

„Jövő év végére át kell adni rendeltetésének a felújított 1 . sz. Katonai Kórházat. A kormány jóváhagyásától, valamint pénzügyi helyzetünktől függően meg kell kezdeni a központi katonai kórház rekonstrukcióját" (7. old.).
„A személyi állomány egészségügyi ellátásáról elmondhatjuk, hogy az 1984ben is tovább javult. Korszerüsödött és hatékonyabbá vált a megelőzés, a gyógyítás és utókezelés rendszere. Korszerüsödött a csapatrendelők felszereltsége. Kórházaink orvosi műszerekkel, készülékekkel való ellátottsága az országos átlagnál jobb.

1984-ben nehezítette az egészségügyi munkát az MN 1. sz. Katonai Kórház felújítása miatti széttelepítés, az MN KKK mind sürgetőbben jelentkező felújítási gondja, a veröcemarosi betegotthon kialakításának elhúzódása.

Komoly gondot jelent a hivatásos orvosok krónikus hiánya. Csapattagozatban a feltöltöttség már csak 66,5\%-os.

A személyi állomány, ezen belül a sorállomány szürővizsgálati adatai szerint a gyakorlatilag egészségesek aránya 1982 óta 96,5\%-os, a hivatásos állományé 64,1\%-os (a szolgálatképesek száma tartósan 80\% körül mozog)" (MN VK AGTCSF 00195/8/1984. 11-12. old.) [63].

\section{5. évi beszámoló az Országgyülés Honvédelmi Bizottságának}

Ez a beszámoló általában a hatodik ötéves tervről ad áttekintést, és az 198185 közötti időszakot értékeli. 1985 egészségügyéről és az elmúlt 5 évről nem szól, de felvázolja az 1986-90 közötti célkitüzéseket, amely a következő: „Az egészségügyi ellátás területén a csapatorvoshiány csökkentését, az intézeti hálózat (Központi Kórház) rekonstrukcióját, továbbá a gyógyító-megelőző munka színvonalának további emelését vettük számításba." (MN VK AGTCSF 00257/10/1985. [63]. 


\section{6. évi beszámoló az Országgyülés Honvédelmi Bizottságának}

„Az egészségügyi ellátás további javítása érdekében megkezdtük az MH Központi Katonai Kórház rekonstrukcióját és az év végéig befejezzük az MN 1. sz. Katonai Kórház felújítását. Javult kórházaink, intézeteink és csapatorvosi rendelőink korszerübb müszerekkel való ellátottsága" (10. old.).

„Egyéb építési feladataink között jelentős helyet foglal el az MN Központi Katonai Kórház rekonstrukciója (14. old.).

Elöször található az anyag mellett számadatokat közlő melléklet. Az 1.sz. melléklet, mely a fö beszerzésekröl és beruházásról, igényekről szól a hetedik ötéves tervre vonatkozóan, de nem tartalmazza a kórház rekonstrukció összegét. (MN VK AGTCSF 0052/8/1986.) [63].

\section{7. évi beszámoló az Országgyülés Honvédelmi Bizottságának}

„Az egészségügyi ellátás javítása érdekében a végrehajtott rekonstrukció után üzembe helyeztük az MN 1. sz. Katonai Kórházat. Folytatjuk az MH Központi Katonai Kórház rekonstrukcióját. Külön fejlesztés keretében számítógépes betegvizsgáló röntgen készüléket helyeztünk üzembe, amely nemcsak az Néphadsereg, hanem a polgári lakosság részére is alkalmazásra kerül." (MN VK AGTCSF 00124/14/1985. 14. old.) [63]].

\section{8. évi beszámoló az Országgyülés Honvédelmi Bizottságának}

Az 1988. évi beszámolónak már címe is van, nevezetesen: „Tájékoztató a HM 1988. évi költségvetésének teljesitéséröl és
1989. évi tervjavaslatról az Országgyülés Honvédelmi Bizottsága részére".

$\mathrm{Ez}$ az alábbiakat írja az 7 oldalon: „A HM nem védelmi célú kiadásain belül (5,190 mFt összesen, amelyből az egészségügy $1,490 \mathrm{mFt}$ ) jelentős öszszeget fordítunk szociális és egészségügyi kiadásokra. Az MN kórházaiban és szanatóriumaiban összesen 2400 ágy áll rendelkezésre. A kórházak kapacitásának mintegy 30\%-át a polgári életből beszállított betegek foglalják el." (MN VK AGTCSF 124/15/1985. 7. old.) [63].

\section{9. évi beszámoló az Országgyülés Honvédelmi Bizottságának}

Az előterjesztés címe: „Tájékoztató a HM 1989. évi költségvetésének teljesitéséröl és az 1990 évi tervjavaslatról az Országgyülés Honvédelmi Bizottsága részére"

„Ez az alábbiakat tartalmazza: „Ezen belül 1,5 mrd Ft-ot (57,6\%-ot) tesznek ki a nem védelmi jellegü beruházások, melynek döntő részre az egészségügyhöz kapcsolódik.(a Központi Katonai Kórház rekonstrukciójára 1989-ben 1,3 mrd Ft-ot fordítottunk.)" (3. old.).

„A Központi Katonai Kórház 1990 évi rekonstrukciójára 1,6 mrd Ft felhasználásával számolunk." (9. old.).

„A 7,3 mrd Ft-ot (17,4\%) nem védelmi célú kiadásokon belül. A döntő részt az egészségügyi, oktatási és szociális ráfordítások képezik, arányuk közel 70\%os" (10. old.).

A MN kórházaiban és szanatóriumaiban 2400 ágy áll a betegek rendelkezésére. A kórházaink gyógyító kapacitásait közel 40\%-ban polgári betegek foglalják el. Anyagi erőforrásaink koncentrálásával mérsékelten javítottuk egészségügyi intézményeink müszerezettségét, felszereltségét. 
„A társadalombiztosítás finanszírozási rendszerének 1990-re tervezett - Országgyülés döntésétől függő - átalakítása ezen a területen alapvető változásokkal fog járni. A tárca egészségügyi intézményeinek finanszírozását is a Társadalombiztosítási Főigazgatóság veszi át, és az erre a célra tervezett 1990. évi támogatási elöirányzat $(1,5 \mathrm{mrd} \mathrm{Ft})$ a tárca keretéből átcsoportosításra kerül.” [MN VK AGTCSF 124/16/1985.[63]].

\section{Irodalom}

[39] HM Titkárság HM KT ülésének anyagai 1985 HL 10d./31 öe.

[40] MN Hadtápfőnökség (MNHF, EüSZF, KSzF, ÉSzF, ÜSzF) 1985 évi nyílt sorszámos rendelkezések HL 1123d./1722 öe.

[42] MNHF Titkos sorszámos rendelkezések 1985 évi HL 1122 d./1720 öe.

[43] HM Titkárság Vegyes Iratok 1982-85.014/ 1985 sz. jegyzőkönyv HL 11 d./34 öe.

[60] HM Titkárság Jemeni, líbiai, bissau-guineai, angolai katonai küldöttségek magyarországi látogatásai 1980-1989 HL 49 d./109 öe.

[61] HM Titkárság Jemeni katonai küldöttségek magyarországi látogatásai 1983,1987. HL 51 d./111 öe.

[62] MN VK szerződések,együttmüködések 1977-1982.HL 156 d./330 öe.

[63] MN VK Anyagtervezési csoportfőnökség (AGTCSF) Beszámolók 1979-1989. HL 677 d./1006 öe.
Lt.General (ret.) Prof. L .Svéd MD, PhD

\section{History of the Medical Service of the Hungarian People's Armed Forces 1980-1989 (Part III)}

Based on request of the Institute of Military History, I conducted research (from the fall of 2016 until the end of 2017) in its archives on history of the Medical Service of the Hungarian People's Army, in order to reveal facts and objectively describe pivotal events of the Medical Service for the period of 1980 to 1989. In the previous two parts of this work, I have described the mission of Medical Service, its everyday health and medical support tasks, its achievements, difficulties and memories. In this part I present my research findings about international relations of the Medical Service (they have been managed with special attention at that time as well), their venues, tasks and health related specifics. Finally, a separate chapter discribes the views of that time management of the Ministry of Defence on Medical Service of the Hungarian People`s Army.

Key-words: Medical Service, Third World and Developing Countries, Warsaw Pact, Hospital named „Yemeni-Hungarian Friendship", Aid, Humanitarian Aid, Report on Temporary Duty, Parliamentary Defense Committee

Prof. Dr. Svéd László ny. o. altbgy., PhD 1134 Budapest, Róbert Károly krt. 44. 